\title{
Reforma Sanitária Brasileira: promessa não cumprida?
}

PAIM, Jairnilson S.

Reforma Sanitária Brasileira: contribuição para a compreensão e crítica.

Salvador: Edufba / Rio de Janeiro: Fiocruz; 2008. 356p.

| ${ }^{1}$ Larissa Shikasho |

1 Psicóloga; mestranda em Saúde Coletiva pela Universidade Federal de Juiz de Fora. Endereço eletrônico: larissashikasho@hotmail.com

O livro Reforma Sanitária Brasileira: contribuição para a compreensão e crítica é uma análise meticulosa, transparente e singular realizada pelo militante e intelectual Jairnilson S. Paim sobre os problemas e desafios da reforma. Trata-se de uma referência obrigatória para estudiosos da Saúde Coletiva e de uma leitura essencial para aqueles que acreditam que há causas pelas quais vale à pena lutar.

No livro, fruto de sua tese de doutorado, Paim direciona a investigação por meio de uma pergunta aparentemente simples, mas um tanto quanto presunçosa: por que a Reforma Sanitária Brasileira (RSB) pode ser considerada uma promessa não cumprida?

A partir de uma vigilância crítica, o autor fundamenta-se no pressuposto de que a Reforma Sanitária é constituinte de uma reforma social e não apenas de uma reforma de natureza setorial e institucional, inerente a uma política social ou de saúde. Recusa, neste sentido, os reducionismos do seu escopo, decorrentes da negação da totalidade de mudanças vislumbradas na Reforma Sanitária.

Do ponto de vista metodológico, Paim tece sua análise embasando-se no discurso expresso em fontes escritas, tais como: entrevistas, publicações técnico-científicas, dissertações e teses registradas no Banco de Dados CAPES, documentos e publicaçôes de instituiçôes e entidades, entre outras evidências que se referem à Reforma Sanitária, apresentando extensa pesquisa documental canalizada na qualidade da revisão bibliográfica presente em seu estudo. 
A pesquisa do autor, em um primeiro momento, se consolida em análises do período de "transição democrática", que partem da fundação do Centro Brasileiro de Estudos da Saúde (CEBES), em 1976, até a promulgação da Constituição da República de 1988, na qual foi fomentada e gerida a proposta da Reforma Sanitária. Em um segundo momento, conduz a análise do período "pós-constituinte" finalizado na "era Lula". O autor buscou identificar, ao longo das distintas conjunturas acima referidas, as produções que se aproximavam ou se tornaram impasses à Reforma Sanitária.

Merecem destaque, no livro, os referencias teóricos centrados nas contribuições marxistas e gramscianas das relaçōes sociais, visto que, embora rechaçadas por alguns estudiosos como "desatualizadas", se apresentam, como defende Paim, passíveis de contextualização para a realidade brasileira, além de terem fundamentado as concepções da Reforma Sanitária. É, portanto, na interlocução com a filosofia da práxis de mudança social que Paim analisa minuciosamente, e com acuidade crítica, os eixos dialeticamente imbricados na ideia, proposta, projeto e processo da RSB.

$\mathrm{Na}$ análise da conjuntura da "transição democrática" (1976 a 1988), o autor inicia sua discussão a partir da crise do "milagre econômico" na década de 1970 e a consequente ampliação dos espaços e discussões políticas, na busca da democratização da sociedade brasileira e do setor saúde. Enfatiza, nesse período, a crescente articulação dos movimentos sociais (trabalhadores, intelectuais, estudantes, operários, dos movimentos populares e da política formal) e a criação das instituições acadêmicas do CEBES e da Associação Brasileira de Saúde Coletiva (ABRASCO). A partir daí, o autor analisa algumas tensōes e conflitos políticos que estiveram presentes no contexto de transição da ideia pouco estruturada à evolução da proposta da Reforma Sanitária. Nesse período, destacam-se a formulação do Programa Nacional de Serviços Básicos de Saúde (PREV-SAÚDE), o Plano de Reorientação da Assistência à Saúde no Âmbito da Previdência Social (Plano do CONASP) e as Ações Integradas de Saúde (AIS).

No que se refere à $8^{a}$ Conferência Nacional de Saúde, Paim discorre sobre os três principais tópicos de discussão: a saúde como direito de cidadania, a reformulação do sistema nacional de saúde e o financiamento do setor. As diversas propostas apresentadas nessa conferência foram descritas e analisadas pelo autor, 
assim como os conflitos derivados dos diferentes interesses de atores políticos, sublinhando as dificuldades de sustentação de um projeto de reforma social que requer ação articulada com um conjunto de políticas sociais mais amplas, relativas ao trabalho, previdência, educação, entre outras. Após a 8a Conferência, foram abordadas a implantação da Comissão Nacional de Reforma Sanitária (CNRS), o Sistema Unificado e Descentralizado de Saúde (SUDS), bem como os embates políticos de tais iniciativas e o próprio processo constituinte.

Ao final da análise desta primeira conjuntura, Paim aponta as ambiguidades e os distintos conceitos apresentados pelos autores da Reforma Sanitária, que a reduziam a uma reforma institucional. Assim, o autor retoma sua definição ao vinculá-la a uma reforma de transformação social, que não deveria se restringir a implementação e conquistas do SUS.

$\mathrm{Na}$ conjuntura pós-constituinte, Paim assinala uma desmobilização do movimento sanitário, inclusive através de seus protagonistas históricos como o CEBES e a ABRASCO, e destaca a atuação de novos sujeitos coletivos no cenário da Reforma Sanitária, como o Conselho Nacional de Secretários da Saúde (CONASS), o Conselho Nacional de Secretários Municipais de Saúde (CONASSEMS) e os Conselhos Municipais, Estaduais e Nacional de Saúde.

$\mathrm{O}$ autor sinaliza que o processo da Reforma Sanitária, ao final do governo Sarney, alavancava retrocessos com a disseminação da ideologia neoliberal, o esvaziamento dos movimentos sociais e o adiamento do envio do projeto de Lei Orgânica da Saúde para o Congresso Nacional. No período Collor, Paim sublinha que, embora a arena política fosse de supremacia do pensamento neoliberal e a ausência de compromissos com o SUS, foram sancionadas as Leis $\mathrm{n}^{\circ} 8.080 / 90$ e 8.142/90. No Governo Itamar, foram abordados os frequentes enclaves com relação ao repasse de recursos para o setor saúde e as ameaças de revisão constitucional. Ainda assim, alguns fatos políticos em seu governo foram assinalados pelo autor, como a descentralização, com a NOB 93, a extinção formal do INAMPS, a interlocução com os movimentos sociais e a criação do Programa de Saúde da Família (PSF).

No governo Fernando Henrique Cardoso, foram destacados os programas de ajuste macroeconômico e a Reforma do Estado, de cunho neoliberal e privatista, que produziram resultados contrários à Reforma Democrática construída pela 
Constituição de 1988 e pelo projeto RSB. Nesse contexto adverso, o autor ressalta o sucateamento das instâncias públicas, resultando no aumento da desigualdade social, no desemprego e piora das condições de vida e saúde.

$\mathrm{Na}$ análise do governo Lula, o autor assinalou a continuidade das políticas de ajuste macroeconômico do governo FHC, e ponderou, ao tratar de alguns avanços setoriais nesse período - como a ampliação da atenção básica, o SAMU, a política de saúde bucal e aprovação do Pacto pela Saúde - que estes não representaram progressos no processo da reforma social prevista na RSB.

Paim apresenta, nos capítulos finais, uma avaliação sobre a práxis da Reforma Sanitária, ao analisar que, mesmo com um elenco significativo de conquistas, a RSB se resumiu a uma reforma parcial de natureza setorial e institucional, traduzida por uma trajetória de implementação tortuosa do SUS. Considera que a revolução passiva seja o elemento que talvez melhor explique a formação social brasileira e a lentidão do processo da RSB, destacando o refluxo das bases sociais de sustentação do movimento sanitário, assim como a necessidade do reencontro e articulação com essas forças.

Trata-se, portanto, de uma obra que incita à reflexão sobre os limites e possibilidades da transformação da sociedade brasileira a partir de uma autêntica transformação política, socioeconômica e cultural e, sobretudo, propicia uma reatualização do compromisso e avaliação crítica dos sujeitos sociais na direção do processo de permanente construção da RSB, de forma a desestabilizar os transformismos em favor das forças progressistas. 